\title{
SOCIAL PERFORMANCE AS A WAY TO STRANGERS COMMUNICATION IN PUBLIC SPACE
}

УдК 1:316.77+304.3+791.9

DOI https://doi.org/

10.32843/2663-5208.2019.10.6

Тімашова О.с.

аспірантка кафедри фрілософії

Національний технічний університет

України «Київський політехнічний

інститут імені Ігоря Сікорського» у статті пропонується новий погляд на соціальний перформанс як спосіб «комунікації незнайомців» у великому місті. У такому соціальному просторі городяни не завжди мають привід для спілкування та реальних контактів, надають перевагу віртуальній комунікації, а побутові потреби реалізують за допомогою автоматизованих процесів. у статті описано френомен «комунікація незнайомців», визначено соціальне підгрунтя для формування відповідного міського запиту і показано роль публічного простору міста як арени, де відбувається така комунікація. Розкриваються роль перформативної компоненти соціального дійства та добровільне контактування акторів соціального персрормансу, визначаються типи взаємодіі між учасниками дійства і публікою.

У дослідженні виявлено дискурсивний модус соціально-комунікативного перформансу сила авторитету. У такий спосіб перформанс репрезентує нову комунікативну модель, яка поступово виміщує патерналістичну модель, традиційно притаманну українському суспільству. Нова авторитетна модель базується на довірі до лідера та вільному виборі дій акторів. Описані процеси сприяють розвитку громадянського суспільства.

У статті розглядається можливість транслювання глобальних ідей і культурних кодів через локальні перформанси, що являють собою концентрований контент. Метою соціального персрормансу виступає викликання емоцій, а ціллю - демонстрація ідеї через дійство. у роботі також розкрито діалектичний вплив на громадську думку арт-технологій, які можуть бути використані в соціальному перформансі. Описано спосіб, в який використання арт-засобів створює реальність, що транслюється через соціальний перформанс. Створена псевдореальність репрезентує ідеї авторів або замовників дійства та може впливати на спосіб життя як представників певних локальних груп, міст, так і нації загалом. Ключові слова: перформанс, «комунікація незнайомців», соціальна взаємодія, комунікація груп, публічний простір, авторитетна модель комунікації, культурний код, публічний простір.

The article offers a new perspective on social performance as a way of "strangers' communicating" in a big city. In such a social space, citizens do not always have an excuse for communication and real contacts, they prefer virtual communication, and they realize their household needs through automated processes. The article describes the phenomenon of "stranger communication", defines the social basis for the formation of a relevant city request and shows the role of public space of the city as an arena where such communication takes place. The role of the performative component of social action and voluntary contacting of actors of social performance is revealed, the types of interaction between the participants of the action and the public are determined.

The study reveals a discursive mode of social and communicative performance - the power of authority. In this way, the performance represents a new communicative model that gradually replaces the paternalistic model traditionally inherent in Ukrainian society. The new, authoritative model is based on trust in the leader and free choice of actions of the actors. The processes described contribute to the development of civil society.

The article deals with the possibility of broadcasting global ideas and cultural codes through local performances, which are concentrated content. The purpose of social performance is to evoke emotions, and the purpose is to demonstrate the idea through action. The work also discusses the dialectical influence of art technologies, that can be used in social performance, on public opinion. We describe the way in which the use of art means creates a reality that is broadcast through social performance. The created pseudo-reality represents the ideas of the authors or customers of the action and can influence the way of life of representatives of certain local groups, cities and the nation as a whole. Key words: performance, social interaction, group communication, public space, authoritative model of communication, cultural code, public space.
Постановка проблеми. Міський простір сьогодення постає як арена міжособистісної комунікації. Оскільки городяни в сучасних містах загалом перевантажені соціальними контактами та намагаються уникнути або сегрегуватися від більшості з них, головним фактором, що усе-таки спонукає до контакту, дедалі частіше стає дія, здатна привернути увагу, захопити її та утримати. Ми вважаємо, що перформанс як репрезентативний засіб взаємодії групи людей виступає нині як потужний засіб міжособистісної комунікації в міському середовищі.

3 нашої точки зору, найактуальнішими проблемами наукової рефлексії $€$ такі, що відповідатимуть на виклики у майбутньому і спонукатимуть людей майбутнього до взаємодії як до еволюційно необхідної форми життєдіяльності. Вже нині ми бачимо, що люди дедалі частіше відмовляються від реальних контактів, 
надаючи перевагу віртуальним. Отже, актуальним є пошук такого виду і форми комунікативної практики, що буде викликати добровільний потяг до комунікації. Саме соціальний перформанс є такою формою, тому його вивчення досить нагальна проблема.

Аналіз останніх досліджень і публікацій. Феномен перформансу було докладно описано на початку 2000-х рр. Провідна роль в аналізі феномена належить культурному соціологу Дж. Александеру, який дав визначення поняття соціального перформансу як колективної соціальної дії [1]. Згодом цей соціокультурний феномен стали розглядати в міждисциплінарному полі: як культурне, мистецьке, соціальне та філософське явище. Д. Гончаренко описує його як суто постмодерністське явище з притаманними йому рисами процесуального мистецтва [14]. Ж.В. Шкляренко розглядає перформанс як арт-практику, що використовує арт- та техно- прийоми для підсилення вражень від дії [11]. Така дія може створювати симулякри, які докладно описав Ж Бодрійяр [12]. М.В. Лігус наголошує, що «соціальний перформанс завжди постає як така соціальна подія, що утверджує горизонтальні стосунки акторів та аудиторії» $[7,52]$. А. Гіденс описував процес становлення самоідентифікації через комунікативні дії [13]. Я. Шумська підкреслює той факт, що участь у перформансі сприяє розвитку громадянського суспільства [10].

Проте не можна забувати про споконвічну проблему відчуження городян у великому місті, яку зазначали ще М. Вебер і Г. Зіммель. Пояснюючи причини відчуження, вони підкреслювали роль детермінант цього процесу: анонімність та байдужість людей натовпу [3; 4]. Міркуючи про комунікацію городян, Л. Лофланд описує три типи соціальних стосунків, що можуть виникати у міському просторі: особистісні, публічні та місцево-локальні [5]. Л. Лофланд та Р. Ольденбург вбачають вихід із ситуації відчуження в організації «третіх місць» (не дім і не офіс) у мегаполісах як специфічного публічного простору комунікації соціальних груп [5], [2]. Проте, незважаючи на чисельність досліджень міської комунікації, ще недостатньо вивчено роль перформативної компоненти, яка заслуговує щільної уваги.

Постановка завдання. Мета статті полягає у висвітленні та аналізі явища соціального перформансу як форми комунікативної практики, що відбувається в міському просторі сьогодення. Завдання статті полягають у виявленні провідних аспектів перформансу. Також задачею статті $€$ опис такого негативного аспекту перформансу, як використання технологій маніпуляцій для трансляції деструктивних ідей.

Виклад основного матеріалу дослідження. У публічному просторі сучасних українських міст набувають дедалі більшої популяр- ності дійства, де, як на сцені театру, акторами (діячами) виступають чи підготовлені заздалегідь особи, чи городяни, які спонтанно втягуються в подію, або частина городян перетворюється на глядачів дійства. Це - соціальний перформанс.

Прикладами такого роду можуть бути ідеологічно різноманітні видовища: хода зі смолоскипами у день народження С. Бандери як акт пошани до національно значущих політичних фігур, Прайд як форма святкової саморепрезентації, «Французька весна у Києві» як репрезентація культури іншої країни. I навіть такий феномен політичного життя, як публічні дебати, що відбулися на стадіоні під час передвиборчої кампанії Президента України 2019 р., демонструє інноваційний перформативний дискурс.

Потрібно зазначити, що підґрунтя для формування саме такого запиту від мешканців великих міст було закладене ще у минулому сторіччі, коли почалося екстенсивне зростання чисельності населення міст і нарощування масштабів мегаполісів. Якість комунікації змінилася докорінним чином, бо городяни внаслідок своєї чисельності перетворилися на «незнайомців» [3]. Зазвичай ця віддаленість при безпосередній фізичній дотичності «призводила до боротьби, а подекуди - і до ненависті» [4]. Проте, попри небажання, боротьбу та неприязнь, необхідність у взаємодії між мешканцями міст залишалася і залишається очевидною, особливо тоді, коли людей об єднує спільна потреба або ідея. Отже, форма і місце міської комунікації поступово почали набувати змін. Яскравим втіленням цих змін стали поліфункціональні публічні місця, які забезпечують локальні відносини між малознайомими людьми [5]. Тож розглянемо, яким чином у мегаполісі відбувається ця «комунікація незнайомців» у дискурсі перформансу.

Ми вважаємо, що локації перформансу будь-якого масштабу можна по праву називати публічним простором. Загалом поняття публічного простору має чимало трактувань. Ми погоджуємося з таким, що пропонує українське урбан-ком'юніті: «Публічний простір - це будь-які повсякденні практики, пов'язані з міським способом життя, - використання міських благ поза межами власного помешкання, споживання, щоденна комунікація» [6]. 3 цього визначення випливає, що комунікація $є$ складником публічного простору, а отже, може мати багато форм, бути дійством як спонтанним, так і заздалегідь підготовленим перформансом, де є сценарій і мета. Факт участі в такому дійстві $€$ первинним приводом для встановлення контакту:

- між акторами,

- між публікою і акторами,

- всередині публіки. 
Розглянемо цю тезу на прикладі такої урбан-практики багатьох міст, як Dresscrossing (безплатний обмін речами), що відбувається в міському просторі: у київському Гідропарку або на Кудрявському бульварі у Києві, або на площі Же де Баль у Брюсселі. Певна активна група городян готує дизайн для перформансу, наповнює його книгами й артефактами, робить перформативні дійства навколо ідеї. А випадкові перехожі при бажанні можуть ставати повноправними учасниками подій. Підкреслимо цей важливий аспект соціального перформансу - добровільний характер взаємодії, без примусу. «Соціальний перформанс завжди постає як соціальна подія, що утверджує горизонтальні (курсив авт.) стосунки акторів та аудиторії», - слушно зазначає і М.В. Лігус [7, с. 52].

Отже, соціальний перформанс у публічному просторі - це відповідь мегаполісу на потребу городян у «комунікації незнайомців», різновид комунікативної практики, який може бути запланованим або спонтанним і відбувається між учасниками дії, утверджуючи їхні «горизонтальні», позастатусні стосунки.

Ще одним важливим аспектом соціального перформансу у публічному просторі $\epsilon$ те, що він транслює силу авторитету, яка також постає як ненасильницька модель комунікації. Авторитетний та харизматичний лідер пропонує варіанти дії для натовпу: долучитися до перформансу або ні, бути безпосереднім спостерігачем, відслідковувати подію в інформаційному просторі або взагалі не бути до неї причетним. Яскравою ілюстрацією цієї тези $€$ відомий заклик М. Наєма на сторінці соціальних мереж у грудні 2013 р., зафіксований у «Щоденнику Майдану»: заклик «випити чаю на Майдані» фактично став початком масового революційного протесту проти чинної влади [8]. I це була саме пропозиція дій, а не чітка інструкція, що притаманна патерналістичній або авторитарній комунікації. Публіка, що отримала цей меседж, кожен з адресатів мав вибір: або долучитися, або залишитися осторонь. Цей перформанс, окрім авторитетного лідера, отримав згодом чітку ідею та сценарні елементи самоорганізації, що дало змогу об'єднатися навколо мети в міському просторі великій кількості незнайомців із різних верств і поколінь. Можна погодитися з думкою О.П. Масюк, що, попри історичний шлях, який пройшло українське суспільство у XX ст., та притаманний тим рокам патерналізм, нині ми «помічаємо тяжіння не до традиційного патерналізму, а саме до авторитетних лідерів» [9]. Цей перехід до авторитетної моделі комунікації говорить, що поступово змінюються окремі соціальні коди та змінюється саме українське суспільство, набуваючи національної самосвідомості.
Перформанс виступає як «яскравий засіб розвитку суспільства, бо надає глядачеві змогу вийти з ролі пасивного спостерігача-споживача, зумовлюючи право побачити в перформансі не стільки те, що бачить автор, а сам глядач, котрий, передусім, зустрічається не з виступом іншого, а із самим собою» $[10$, c. 86].

Таким чином, можна стверджувати, що соціальний перформанс у публічному просторі міста втілює функцію ретранслятора соціальних кодів, що перебувають у стані трансформації або вже змінилися, і нині спостерігається тяжіння локальних громад, скоріше, до авторитетної сили, аніж до авторитарної.

Говорячи про інші аспекти соціального перформансу у місті, неможливо оминути вкрай важливу його складову частину - технології. Оскільки головною метою перформансу є пробудження почуття та емоцій, закономірно, що в реалізації дійств використовуються технології, що посилюють «ефект враження». «Різні технічні можливості дають змогу мистецтву перформансу поширюватися на медіа-сферу, залучаючи в дійство «технічні» мистецтва для синтезу: відео-арт (робота з відео і телевізійними іміджами); теле-комюнікейшн-арт (як художній простір використовується віртуальна реальність); відеоінсталяції (конструкції з телевізійних чи відеопристроїв); нет-арт (постійно змінюване мережеве мистецтво в інтернеті, що трансформується користувачами)» [11, с. 45]. За допомогою технічних рішень та обладнання і за допомогою цифрових технологій створюються візуальні та аудіальні образи, що транслюють специфічні символи та коди для публіки і цілеспрямовано впливають на неї. Перформанс може бути використаний його замовником як спосіб створення або поширення «симулякру або копії реальності, що не має оригіналу» [12]. Прикладом такого перформансу $є$ горезвісні афери «еліт-центрів». За допомогою високотехнологічної реклами для покупця створюється образ благополучного «райського» життя, яке на нього чекає після придбання нерухомості, а в реальності будинку не існує, або він залишається недобудованим. Отже, ідеєю перформансу у цьому разі постає обман із метою наживи.

Звернемо увагу на культурні перформанси, наприклад, на вуличні вистави театру «Дах» В. Троїцького, де також використовуються сучасні технологічні і візуальні засоби спливу на публіку. Можна зазначити, що у цьому разі вони служили суспільному благу, доповнювалися трансляцією українського коду у співах та образах, що поставало ключовим змістом передачі національної ідентичності. Водночас із тим актори під час такого театрального дійства, виконуючи сценарні дії, “створювали і власний наратив самоідентичності» [13]. 
Проте, повторимо, сучасні засоби та прийоми театралізації можуть бути використані і для просування деструктивних ідей. За допомогою технологічних спецефектів можна «атакувати» свідомість громадян у потрібному замовникам напрямі. «Однією з характерних рис перформанс-арту є симуляція реальності, внаслідок якої застосовуються практики підміни справжніх і умовних понять, зсунення акцентів і звичних відправних точок реального та штучного, і, зрештою, знищення кордонів між мистецтвом і життям», - слушно підкреслює вплив перформансів Д. Гончаренко [14, с. 335]. Прикладом таких перформансів-ретрансляторів деструктивних ідей в істоpiї $€$ паради нацистів у Німеччині на початку XX cт., де головною ідеєю виступала ідея елітарності нації, а сукупність візуально-акустичних засобів посилювала вплив промови вождів Рейху перед натовпом.

Можливо, аби уникнути маніпулятивного впливу, городянин свідомо має ігнорувати перформанси, відмовлятися брати участь у них?... Проте така стратегія обмежує свободу і суперечить здоровому глузду. Мабуть, єдиним виходом у цьому разі є критичне мислення і відслідковування власних несподіваних реакцій, афектів, почуттів ейфорії, ненависті, прихильності тощо, які виникають внаслідок розгортання перформансу.

Висновки $з$ проведеного дослідження. Таким чином, ми розглянули деякі аспекти соціального перформансу в публічному просторі міста і виявили, що саме такий спосіб комунікації виступає каталізатором «спілкування незнайомців», які потенційно можуть об'єднатися навколо спільної ідеї.

Провідними аспектами перформансу $€$ такі:

1) перформанс являє собою ненасильницький спосіб комунікації;

2) у сучасних перформансах використовується авторитетна форма комунікації, яка забезпечує добровільний вибір участі городян або у ролі акторів, або у ролі спостерігачів дійства;

3) перформанс являє собою концентрований контент, динамічне викладення ідей, що викликає емоційне переживання, здатне поєднувати різні страти та покоління городян, презентувати спільні культурні коди для соціальних груп;

4) перформанс може виступати як поштовхом до змін, так і безпосереднім ретранслятором суспільних трансформацій.

Тема міських перформансів здається нам досить плідною, і ми бачимо ії продовження в компаративістському аналізі різножанрових дійств у великих містах з інтернаціональним населенням.

\section{ЛITEPATУРA:}

1. Alexander J.C., Giesen B., Mast J.L. (2006). Social performance: symbolic action, cultural pragmatics, and ritual. Cambridge : Cambridge University Press, 2006.

2. Ольденбург Р. Третье место: кафе, кофейни, книжные магазины, бары, салоны красоты и другие места «тусовок» как фундамент сообщества / Пер. с англ. А. Широкановой. Москва : Новое литературное обозрение, 2014. 456 с.

3. Вебер М. Город. Избранные произведения. Москва : Прогресс, 1990.808 с

4. Зиммель Г. Большие города и духовная жизнь. Логос. 2002. № 3-4.

5. Лофрланд Л. Соціальні взаємозв'язки. Соціальні стратегії в суспільстві. Москва : Литкон, 2017. 119 с.

6. Тищенко І. Що таке міський публічний простір. URL: https://mistosite.org.ua/ru/articles/shcho-takemiskyi-publichnyi-prostir

7. Лігус М.В. Поняття перформансу: соціально-фрілософрський аспект. Молодий вчений. 2017. № 7 (47). С. 51-54.

8. Щоденник майдану. URL: https:// www.istpravda.com.ua/articles/2015/02/17/147354/

9. Масюк О.П. Патерналізм як об'єкт соціально-фрілософської рефрлексії : авторефр. дис. ... канд. філософр. наук : Запоріжжя, 2006. 17 с.

10. Шумська Я. Зв'язок минулого і сьогодення у мистецтві перформансу. Вісник Львівської національної академії мистецтв. 2017. № 23. С. 78-87.

11. Шкляренко Ж.В. Міждисциплінарний характер перформансу. Science Review. 2018. № 5 (12). C. 44-46.

12. Бодрийяр Ж. Симулякры и симуляция / пер. с фрр. А. Качалова. Москва : Рипол-классик, 2015.

13. Giddens A. Modernity and self-identity. Stanford, 1991.

14. Гончаренко Д. Перформанс-арт як явище культури постмодернізму. Актуальні проблеми мистецької практики і мистецтвознавчої науки. 2013. Вип. 5. С. 333-337. 